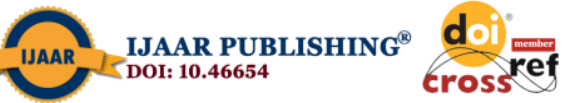

International Journal of Advanced Academic Research (Social and Management Sciences) | ISSN: 2488-9849

Vol. 6, Issue 12 (December, 2020) | www.ijaar.org

Journal DOI: 10.46654/ij.24889849

Article DOI: 10.46654/ij.24889849.s61212

\title{
CHANGE MANAGEMENT AND ORGANISATIONAL PERFORMANCE OF BANKS IN PORT HARCOURT, RIVERS STATE
}

\author{
Nwaohiri Maximus Onyema \\ Management Department, \\ University of Port Harcourt Business School, \\ Port Harcourt, Rivers State. \\ B. Chima Onuoha \\ Department of Management, \\ University of Port Harcourt, Choba, Rivers State, Nigeria.
}

\begin{abstract}
This study took an empirical investigation on the relationship between change management and organizational performance of banks in Port Harcourt, Rivers State, Nigeria. The study adopted the descriptive survey design and employed primary data. A sample size of 218 employees was randomly selected and responses obtained using a structured questionnaire. The Spearman rank correlation coefficient was utilized in analyzing the primary data and hypothesis tested using the probability approach. The study found a positive significant correlation between technological change and net profit. Leadership change has positive significant effect on net profit. The study concludes that change management influences organizational performance of banks in Port Harcourt, Rivers State. The paper recommends that banks adopt the latest technology and ensure clear and transparent communication of change policies to employees.
\end{abstract}

Keywords: Change Management, Organisational Performance, Banks, Port Harcourt. 
International Journal of Advanced Academic Research (Social and Management Sciences) | ISSN: 2488-9849

Journal DOI: 10.46654/ij.24889849

Vol. 6, Issue 12 (December, 2020) | www.ijaar.org

Article DOI: 10.46654/ij.24889849.s61212

\section{Introduction}

In today's business environment, nothing remains still. The rate of change which business organizations face continues to increase more and more in the last five decades (Huselid, 2005). This is as a result of advances in information and communication technology increasing democratization of economies and liberalization of economies across the globe. "Change" has now become inevitable and turns to be a regular feature of business life. It is pertinent therefore, that it receives the necessary attention (from management) in order to guarantee a continued increase in business performance (Okeke, Oboreh, Nebolisa \& Esione, 2019). The world today is a global village enhanced by the use of technology. Organizations at remote places need to communicate with multinationals as well as the world at large in order to be abreast with the ever-changing business world. There is the need for organizations to adapt to systems that can effectively give the organizations a timely boost in terms of its employee's productivity as well as increased profitability. The use of the internet has made so much information available to today's organizations and their management teams. Information is available in the internet concerning virtually everything, be it the latest updates in the business, partnership, advertisement, purchases, equipment and machines etc. Some of the common drivers of change include; adjusting to shifting economic conditions, adjusting to changing landscape of the marketplace, complying with government regulations and guidelines, meeting clients' needs, taking advantage of new technologies as well as addressing employees' suggestions for improvement (Nwinyokpugi, 2018).

Business environment across the globe has become increasingly volatile and constantly changing in the last few decades. The banking industry has been the hardest hit of all, because it is central to the globalization process that is on course. The competition in the banking industry is intense. Managers in this industry today do not stimulate change but encourage adaptation and innovation in order to improve products and services, to meet new pressures and demands. The Nigerian banking industry was for almost three decades after independence underperforming and the industry remained nonprofitable and most cases epileptic in functioning. However, at the coming of another democratic dispensation in 1999 (after several years of military rule in the country), the industry became one of the areas that the then leader Olusegun Obasanjo through the Governor of Central Bank, Prof Soludo increased the capital base of banks to N25 billion.

To achieve varied goals, managers need more than fragmentary ad-hoc change programs dealing only with present challenges. They need change management methods to prepare for upcoming organizational competitive difficulties. Managers must gain knowledge on how to build and manage a human group that is proficient in foreseeing the new, capable of changing its vision into technology, products, processes and services, willing and able to agree with the new. Attempts to execute change management have been many and extensive, but the promises made in its name have remained unsatisfied (Daniel, 2019). Osisioma (2004) argues that change is the single most important element of successful business management today and as such, it is a fact of life that organization managers should anticipate change in order to remain competitive in increasingly aggressive markets and adopt a positive attitude to it since this is inevitable in the history of any organization. Ignoring or trivializing a changing trend can be costly, thus managing change teaches managers how to be ahead of rivals and it ensures the long-term survival of organizations (Daniel, 2019). 
Udeh and Igwe (2013) stated that while change can cause confusion and fear, there are several positive effects it can have on organizational performance if handled properly. Understanding the positive effects of change helps to better measure progress in developing change management policies within the organization. As opined by Westenholz (2013), change is a necessity even in the face of the many challenges confronting banks in Nigeria. The consequences of a transformation failure include: reduced organizational effectiveness, wasted resources, employee cynicism, dampened employee morale, loss of integrity for those leading the effort and reduced ability to confront and compete in the environment for needed resources and support (Iyayi, 2000). Organizations failing to introduce change successfully can pay a high price; failure can lead to loss of market position, and the credibility with stakeholders as well as decreased morale among management and staff, resulting in a de-motivated workforce or worse still, the loss of key employee (Edmonds, 2010; Okonji, Olayemi \& Oghojafor, 2017).

This study is to examine change management and organizational performance of banks in Port Harcourt, Nigeria. In view of this, the following objectives were outlined to be achieved:

i. Examine the effect of technological changes on net profit of banks in Port Harcourt.

ii. Determine the effect of leadership changes on net profit of banks in Port Harcourt.

In line with the purpose of this paper, the following questions were posed:

i. Does organizational change significantly increase net profit of banks in Port Harcourt, Rivers State?

ii. Does leadership change significantly increase net profit of banks in Port Harcourt, Rivers State?

The study formulated the following hypotheses to help actualize the research objectives:

1. Technological change does not result in increase in net profit of banks in Port Harcourt, Rivers State.

2. Leadership change will not bring about increase in net profit of banks in Port Harcourt, Rivers State.

\section{Review of Related Literature}

\section{Concept of Change Management}

Change basically means series of events which support the process of development in organizations (Kassim, Tahajuddin, Shahzad, Isa, \& Mat, 2010). Korir, Mukotive, Loice \& Kimeli (2012) defined change management as the effective management of a business change such that executive leaders, managers and frontline employers work in concert to successfully implement the needed process, technology or organizational changes. Armstrong (2009) notes that Change Management (CM) emphasizes the need for the change management plans, and strategies to be formulated within the context of overall organizational strategies and objectives and to be responsive to the changing nature of the organization's external environment. Moran and Brighton (2011) defined change management as the process of continually renewing an organization direction, structure and capabilities to serve the ever changing needs of external and internal customers. Management of 
change is the systemic approach and application of knowledge, tools and resources to deal with change. Management of change means "defining and adopting corporate strategies, structures, procedures and technologies to deal with changes in external conditions and the business environment" (Bond, 2008).

\section{Organizational Performance}

According to Daft (2000), organizational performance is defined as an organization's ability to attain its goals by using resources in an efficient and effective manner. Consequently, it is an evidence of the output of members of an organization measured in terms of revenue, profit, growth, development and expansion of the organization. Enos (2007) defines organization performance as an indicator and progressive achievement of tangible, specific, measurable, worthwhile and personally meaningful goals. Organizational performance can also be used to view how an enterprise is doing in terms of level of profit, market share and product quality in relation to other enterprises in the same industry. Accordingly, it is a reflection of productivity of members of an enterprise measured in terms of revenue, profit, growth, development and expansion of the organization (Kehinde, Jegede, and Akinlabi, 2012).

\section{Theoretical Framework}

\section{Lewin's Three Step Model}

Lewin (1952) developed a three-phase model of change, based on the premise that an understanding of critical steps in the change process increases the likelihood of the successful management of change. These steps in the process are:

Unfreezing: This stage involves the recognition of the need to change. Action is taken to unfreeze the existing attitudes and behaviour, which is essential for supporting employees and minimizing change resistance (Linstead et al., 2009). Lewin believed that the stability of human behavior was based on a quasi-stationary equilibrium supported by a complex field driving and restraining forces (Burnes, 2004; Okeke, Oboreh, Nebolisa \& Esione, 2019).

Changing: As Schein (1992) notes, "unfreezing is not an end to itself, it creates a motivation to learn but does not necessarily control or predict the direction". This echoes Lewin (1952), that any attempt to predict or identify a specific outcome from planned change is very difficult because of the complexity of the forces concerned (Burnes, 2004). Moving the organization to the desired state involves actual implementation of new systems of operation. This may involve experimentation, modification of systems or patterns of behaviour, (Linstead, Fulop \& Lilley, 2009). Once the change appears to have reached equilibrium once more, it is time for the next process.

Refreezing: This stage involves the positive reinforcement of desired outcomes to promote the internalization of new attitudes and behaviors. An appraisal of the change program becomes necessary at this stage to ensure that the new way of operating becomes a matter of habit, not a regulation. Burnes (2004) adds that "refreezing seeks to stabilize the group at a new quasi-stationary equilibrium in order to ensure that the new behavior is relatively safe from regression". 
International Journal of Advanced Academic Research (Social and Management Sciences) | ISSN: 2488-9849

Journal DOI: 10.46654/ij.24889849

Vol. 6, Issue 12 (December, 2020) | www.ijaar.org

Article DOI: 10.46654/ij.24889849.s61212

\section{Action Research Model}

Action research is a combination of changing not only attitudes and behavior, but also testing the change method being utilized (McShane \& VonGlinow, 2005; Collier, 1945; Lewin, 1945, 1951; French, 1969; Schein, 1980; Argyris, 1970, 1968). The first part of the change process must be action-oriented because the ultimate goal is to make change happen. The second part revolves around trying different frameworks in a real situation to verify whether or not the theories really work or applying the various theories in various situations that require change. The process of action research is first to diagnose a need for change (unfreezing), then to introduce an intervention (moving) and finally to evaluate and stabilize change (refreezing). Each of these steps in the process is consistent with the three stages in Lewin's Model (Thomas, 2014).

\section{Empirical Review}

Warrilow, (2010) in his work stated that to effectively manage change in an environment experiencing change dynamics, there is a need to adopt strategies for managing such changes so that people can embrace change and direct it towards positive contribution of a given organization. He therefore suggested the strategies for managing change. He further stated that when opting for a strategy, we should take into account not only the circumstances we face, but also the preferred managerial style.

Ahmed, Rehman, ZAsad, Hussain and Bilal (2013) examined the impact of organizational change on the employee performance in the banking sector of Pakistan. In this study, Primary and secondary data collection techniques were used for obtaining data. Copies of the questionnaire were used for primary data collection. Leadership, communication, procedural justice, employee development, tolerance to change are the variables considered for the study. The sample size was 252, hence descriptive statistics and correlation analysis techniques were used for the analysis of data in SPSS software. The results showed that organizational change had a positive significant impact on employee performance in the banking sector of Pakistan.

Miller and Friesen, (2000) observed that employees tend to show resistance to change even when their environment threaten them with extinction.

Giauque (2015) examined the attitudes towards organizational change among public middle managers. This study aims to identify social and organizational antecedents of positive attitudes towards change. The investigated population is composed of middle managers working in Swiss public hospitals which are currently being confronted by major reforms. Partial mediation effects of organizational commitment in the relationships between independent variables and PATC were also controlled. The findings showed that perceived social support (work relationships with colleagues and supervisors) as well as perceived organizational support (employee voice and participation; information and communication; work-life balance) are positively and significantly related to PATC. Stress perception is shown to have a negative impact on PATC.

Ndahiro, Shukla and Oduor (2015) examined the effect of change management on the performance of government institutions in Rwanda. The study adopted survey research design, and the target population of employees of RRA. Data was collected using questionnaires and interviews and analyzed using SPSS and Microsoft Excel. Based on the data collected, the study concluded that all 
changes made in RRA in the past four years have been well planned and implemented. Most of the employees in the institution have generally embraced the changes made in the organization, and resulted to overall organizational performance.

Olajide (2014) carried out a research on change management and its effect on organizational performance of Nigerian telecoms industries, using empirical insight from Airtel Nigeria. A total of 300 staff of Airtel was randomly selected from a staff population of 1000. Three hypotheses were advanced to guide the study and data collected for the study were analyzed using One-way Analysis of Variance. The result revealed that changes in technology had a significant effect on performance and that changes in customer taste has a significant effect on customers' patronage. The result also shows that changes in management via leadership had significant effect on employee's performance. Aregbeyen (2011) found mixed relationship between change and organizational performance.

\section{Methodology}

This study adopted the descriptive survey design in its generation of data for assessing the relationship between change management and organizational performance. The study was carried out in Rivers State. Primary data were employed in the study. These were sourced through the use of questionnaire administered to the respondents selected for the study. The population was 218 working at the selected banks in Port Harcourt, Rivers State. The entire population was used as the sample; therefore, the sample size was 218. The major instrument used for data collection was the questionnaire. Content validity was adopted, and the researchers used test-retest method in order to test reliability of the research instrument. Spearman rank correlation technique was used in analyzing the primary data. The statistical package for social sciences (SPSS) version 22 was employed to test the hypotheses.

\section{Results and Discussion}

Here, we present the results of the Spearman correlation technique and conduct the test of significance using the probability approach. The decision rule is that, we reject the null hypothesis of no significant relationship between the two variables and accept the alternative hypothesis, if the probability value is less than 0.05 or 5 percent. We will reject the null hypothesis if the probability value of correlation coefficient is greater than 0.05 .

\section{Test of Hypotheses}

Here, the study examines the correlation between change management and organizational performance of banks in Port Harcourt, Rivers State and test the formulated hypotheses expressed in the foremost section of this paper.

\section{Hypothesis One}

$\mathrm{H}_{01}$ : There is no significant relationship between technological change and net profit of banks in Port Harcourt, Rivers State. 
Table 1: Correlation analysis showing the relationship between technological change and net profit of banks in Port Harcourt, Rivers State

\section{Correlations}

\begin{tabular}{|c|c|c|c|c|}
\hline & & & $\begin{array}{c}\text { Technological_ } \\
\text { Change }\end{array}$ & Net_Profit \\
\hline \multirow{6}{*}{ Spearman's rho } & \multirow{3}{*}{ Technological_Change } & Correlation Coefficient & 1.000 & $.617^{* *}$ \\
\hline & & Sig. (2-tailed) & & .000 \\
\hline & & $\mathrm{N}$ & 218 & 218 \\
\hline & \multirow{3}{*}{ Net_Profit } & Correlation Coefficient & $.617^{* *}$ & 1.000 \\
\hline & & Sig. (2-tailed) & .000 & \\
\hline & & $\mathrm{N}$ & 218 & 218 \\
\hline
\end{tabular}

**. Correlation is significant at the 0.01 level (2-tailed).

\section{Source: Own computation using SPSS 22}

The table above reports the correlation analysis between technological change and net profit. From the empirical result above, technological change and net profit correlate at .617 as the probability value of .000 is less than 0.05 level of significance. This suggests that there is a strong positive relationship between technological change and net profit of banks in Port Harcourt, Rivers State. Thus, we reject the null hypothesis of no significant relationship and accept the alternative, which stipulates that, there is a significant relationship between technological change and net profit of banks in Port Harcourt, Rivers State. Our findings reaffirm those put forward by Olajide (2014) which stresses on the significant positive impact technological change has on organizational performance. However, our findings deviate from those of Aregbeyen (2011) which found mixed relationship between technological change and organizational performance.

\section{Hypothesis Two}

$\mathrm{H}_{02}$ : There is no significant relationship between leadership change and net profit of banks in Port Harcourt, Rivers State. 
Table 2: Correlation analysis showing the relationship between leadership change and net profit of banks in Port Harcourt, Rivers State.

\section{Correlations}

\begin{tabular}{|c|c|c|c|c|}
\hline & & & $\begin{array}{c}\text { Leadership_ } \\
\text { Change }\end{array}$ & Net_Profit \\
\hline \multirow{6}{*}{ Spearman's rho } & \multirow{3}{*}{ Leadership_Change } & Correlation Coefficient & 1.000 & $.735^{* *}$ \\
\hline & & Sig. (2-tailed) & & .000 \\
\hline & & $\mathrm{N}$ & 218 & 218 \\
\hline & \multirow{3}{*}{ Net_Profit } & Correlation Coefficient & $.735^{* * *}$ & 1.000 \\
\hline & & Sig. (2-tailed) & .000 & \\
\hline & & $\mathrm{N}$ & 218 & 218 \\
\hline
\end{tabular}

**. Correlation is significant at the 0.01 level (2-tailed).

\section{Source: Own computation using SPSS 22}

Table 2 above presents the outcome of the Spearman rank correlation. As revealed by the result above, a positive relationship was found to exist between leadership change and net profit of banks in Port Harcourt, Rivers State. Further examination showed that, the positive relationship between leadership change and net profit is significant as the probability value of 0.000 is below the 5 percent (0.05) level of significance. Thus, we reject the null hypothesis and accept the alternative of significant relationship between leadership change and net profit of banks in Port Harcourt, Rivers State. The study finding is in line with the discoveries made by Ndahiro, Shukla and Oduor (2015) and Ahmed, Rehman, ZAsad, Hussain and Bilal(2013) which confirms that organizational change has significant positive impact on the performance of organizations.

\section{Conclusion and Recommendations}

This work investigated the effect of change management on organizational performance of banks in Port Harcourt, Rivers State. The study employed primary data sourced using a structured questionnaire and administered to 218 employees drawn from seven commercial banks in Port Harcourt. From the discoveries of the study, we found that technological change has significant effect on the organizational performance of banks. Also, the study discovered that leadership change exerts significant effect on organizational performance. Conclusively, the study holds that change management positively and significantly affect the organization performance of banks in Port Harcourt, Rivers State. The study made the following recommendations based on the findings of the paper:

i. Organization should adopt the latest technology in vogue, better and embracing communication techniques and ensure their usage in training employees in order to raise their performance and productivity level.

ii. The study recommends a systematic implementation of change instituted in the organization and proposed a top-to-bottom initiation of change and a clear communication of such changes to the employees. 
International Journal of Advanced Academic Research (Social and Management Sciences) | ISSN: 2488-9849

Journal DOI: 10.46654/ij.24889849

Vol. 6, Issue 12 (December, 2020) | www.ijaar.org

Article DOI: 10.46654/ij.24889849.s61212

\section{REFERENCES}

Ahmed, Z., Rehman, Z.U., Asad, A., Hussain, N. \& Bilal, A. (2013). The impact of organizational change on the employee's performance in banking sector of Pakistan. Ethiopian International Journal of Multidisciplinary Research, 1(1):1-12

Armstrong, M. (2009). A hand book of human resource management practice. USA: Prentice HallInc.

Bond, C. (2008) Outcome Realization and Organizational Change Management- the Tasmania Government Approach, Department of Premier and Cabinet, Tasmania.

Burnes, B. (2004), Managing change: A strategic approach to organization dynamics, $4^{\text {th }}$ edition. London: Pitman Publishing.

Daft, R. L. (2000). Organization Theory and Design, 7th ed., Cincinatti: South-Western Thomson.

Daniel, C. O. (2019). Effects of Change Management on the Performance of Firms in Nigeria. International Journal of Advances in Scientific Research and Engineering, 5(1), 59-64.

Edmonds, J. (2011). Managing successful change. Industrial and commercial training, 43(6), 349353.

Iyayi, F. (2000). Sustaining Organization Transformation Efforts in Nigeria. Management Review, 11(7), 777-792.

Ju-Chun, C. (2015). The impact of change management on employee satisfaction and engagement. International Journal of Social, Behavioral, Educational, Economic, Business and Industrial Engineering, 9 (5),1680-1685.

Kassim, A.W., Tahajuddin, S.B., Shahzad, A., Isa, E.V., \& Mat, N. (2010). Preliminary insights into the role of space in organizational change. The Journal of International Management Studies, $5(2), 50-58$.

Kehinde, J. S, Jegede, C.A. \& Akinlabi, H.B.(2012). Impact of Leadership Skill and Strategies on Banking Sector Performance: A Survey of Selected Consolidated Banks in Nigeria. The Business and Management Review, 3 (1): 313-319.

KorirJ, Mukolive E, Loice, C. \& Kimeli, D. (2012). Change management effects on hotel performance: Journal of social science tomorrow1(80)123-131.

Lewin, K. (1952). Frontiers in group dynamics in field theory in social science. Selected Theoretical Papers. Tavistock Publications.

Linstead, S., Fulop, L. \& Lilley, S. (2009). Management and organisation: Acritical text. $2^{\text {nd }}$ ed. United States: Pelgrave Macmillan.

Ndahiro, S., Shukla, J. \& Oduor, D. (2015). Effect of change management on the performance of government institutions in Rwanda: A Case of Rwanda Revenue Authority. International Journal of Business and Management Review, 3(5)95- 107. 
International Journal of Advanced Academic Research (Social and Management Sciences) | ISSN: 2488-9849

Journal DOI: 10.46654/ij.24889849

Vol. 6, Issue 12 (December, 2020)| www.ijaar.org

Article DOI: 10.46654/ij.24889849.s61212

Nwinyokpugi, P. N. (2018). Organizational Change Management and Employees Productivity in the Nigeria Banking Sector. IOSR Journal of Business and Management (IOSR-JBM), 20(1), 11 20 .

Okeke, M. N., Oboreh, J. C., Nebolisa, O., \&Esione, U. O. (2019). Change Management and Organizational Performance in Selected Manufacturing Companies. The International Journal of Social Sciences and Humanities Invention, 6(5), 5437-5445.

Olajide, O.T. (2014). Change management and its effects on organizational performance of Nigerian telecoms industries: Empirical insight from Airtel Nigeria. International Journal of Humanities, Social Sciences and Education, 1(11), 170- 179.

Osisioma, B. C. (2004). Management of Change: An Overview of the Nigerian Corporate Profile. Management in Nigeria, 40(2), 3.

Thomas, O. O. (2014). Change management and its effects on organizational performance of Nigerian telecoms industries: Empirical Insight from Airtel Nigeria. International journal of humanities social sciences and education (IJHSSE), 1(11), 170-179.

Udeh, S. N., \&Igwe, N. N. (2013). Effects of mergers and acquisitions on return on capital employed and dividend per share indices of companies in Nigeria. International Journal of Business Administration, 4(5), 51-72.

Westenholz, A. (2009). Main Aspects Regarding the Implication of Change Management in an Organization. Research in the Sociology of Organizations, 27(1). 